\title{
The relationship between psychological contract and voice behavior-a social exchange perspective
}

\author{
Khalid Rasheed Memon ${ }^{1}$ (i) $\cdot$ Bilqees Ghani ${ }^{2}$
}

Received: 16 February 2020 / Accepted: 14 September 2020 / Published online: 18 September 2020

(C) Springer Nature B.V. 2020

\begin{abstract}
Our study explores the relationship between psychological contract (fulfillment/violations) and voice behavior (promotive/prohibitive). The study encourages promoting the development of positive voice behavior since the promotive voice behavior of employees would help the organization to grow and improve as per industry standards especially during the upcoming hi-tech era. If the knowledge workers do not show positive voice behavior, it is difficult for organizations to compete and sustain in such an era of digitalization. A cross-sectional survey was conducted for the assessment/ validation of the model. Data was collected through a single self-reported questionnaire, filled out by the 89 employees of two private banks, working in 8 different branches. Further, the relationships among variables have been analyzed using structure equation modeling. Results show a strong and positive relationship between psychological contract fulfillment and promotive voice behavior whereas a negative relationship is indicated upon the violations and breach of psychological contract. Job satisfaction/dissatisfaction was also tested as mediators between these variables. Future researchers may test the same in different geographical locations and demographic conditions, whereas various personality traits may also be tested since voice behavior is an individual decision. The study represents the first of its kind on the said topic especially in the Pakistani context.
\end{abstract}

Keywords Voice behavior · Psychological contract · Perceived organization Support · Job satisfaction · Social exchange theory

Khalid Rasheed Memon

khalidilm@hotmail.com

Bilqees Ghani

bilqees.ghani@gmail.com

1 Graduate School of Business, University Sains Malaysia, Penang, Malaysia

2 College of Business Management, Institute of Business Management, Karachi, Pakistan 


\section{Introduction}

It has become difficult for both the employee and organization to meet each other's expectations, which form the foundation of exchange relationships based on mutual trust and cooperation. At one end, employer demands to have employees who are more innovative, idea generating, taking initiatives, speaking up, and taking responsibility and can bring improvement in the organization due to complex market conditions, tough competition, globalization, cost cuttings, etc. (Nikolaou et al. 2008). Further, downsizing, restructuring, market pressures, technological advancements etc. (Bartodziej 2017; Turnley and Feldman 2000) do not allow the organizations to fulfill its commitments and psychological contracts even if they have the best intentions to do so (Zagenczyk et al. 2011) resulting in psychological contract violations and breach (Hui et al. 2004).

On the other end, employees have become more knowledgeable and demanding with implicit expectations of care, safety and consideration, long-term commitments, etc. (psychological contracts) (O’Donohue and Sheehan 2007). Further, employees now expect greater organizational and leader support for their work efforts, on the basis of exchange ideology favoring the trade of work effort for material and symbolic benefits (Eisenberger et al. 1986; Memon et al. 2018).

Such exchange ideologies are embedded with the feelings of helping those who are helping you, influenced through perceived organizational support through its policies and procedures, for instance, appraisals, pay and reward, job enrichment, etc., and leaders' behavior judged by their statements, their frequency, extremity and sincerity and approval of praise, support and care, etc., i.e., implicit/explicit expectations or fulfillment of psychological contract (Blau 1964; Eisenberger et al. 1986; Wayne et al. 1997). Most of these factors are the antecedents of job satisfaction (Knights and Kennedy 2005) whereas job satisfaction is the antecedent of voice behavior as explored by a number of studies (Nikolaou et al. 2008)

Literature considers voice behavior as extra role behavior (Liu et al. 2010) representing the reciprocatory behavior of employees in response to the favors that the organization and their supervisors have done to them, and thus, as a norm, they do raise their voice intensely (Cropanzano and Mitchell 2005). The purpose of raising voice is to help organizations to identify and improve operational problems (Morrison 2011) overlooked by supervisors and generate innovative ideas in routine functioning of organizations, on a voluntary basis ( $\mathrm{Ng}$ and Feldman 2011). Voice behavior occurs when an individual employee observes a problem that should be dealt with. Importantly, the employees must be motivated enough to say something about the problem, because pointing out such problems is not technically part of their job (Raub and Robert 2012; Memon 2014). Thus voice behavior is advantageous not only as a form of communication but also as a resource of change-oriented communication intended to improve the situation (Nikolaou et al. 2008; Engemann and Scott 2020). Further, withholding of information and ideas can undermine organizational decision-making, error correction and development, and innovation processes; therefore, speaking up, especially in those organizations which are passing through restructuring or facing difficult situations, is highly appraised and positively accepted in the organizations (Nikolaou et al. 2008; Premeaux and Bedeian (2003).

A number of researches have been conducted earlier in western countries, i.e., developed nations regarding this important construct of psychological contract due to 
its increased importance in today's turbulent market conditions, however, lesser research has been conducted in developing countries (Hui et al. 2004)This research examined the relationship and the possible mechanism of psychological contract fulfillment and psychological contract violations on employee's contribution, i.e., voice behavior of the employee. Most of the previous researches on the construct of psychological contract have been conducted on OCB (Coyle-Shapiro and Kessler 2000; Turnley et al. 2003), organizational commitment (Antonaki and Trivellas 2014; Knights and Kennedy 2005), employee intention to quit (Turnley and Feldman 2000) or overall EVLN model with dissatisfying organizational situations (Lee and Varon 2020) etc. Further, the authors Antonaki and Trivellas (2014) have noted that most psychological contract research has been conducted either in the USA or the UK, using as samples MBA students or graduates, with or without working experience. There is scarcity of researches which examine the impact of psychological contract directly on employees in a developing country's context. Therefore, such a research within a developing country's context would be a valuable contribution.

Another contribution of this article is to explore the impact of psychological contract (fulfillment/violations) on employees' voice behavior in the light of Social Exchange Theory as most of the systematic research has focused on individual differences (Detert and Burris 2007) such as personality, as correlates of Voice (LePine and Van Dyne 2001; LePine and Dyne 1998), voice in safety-oriented organizations (Engemann and Scott 2020) instead of contextual factors (the organizational conditions that facilitate or inhibit voice behavior) or the researches have been carried out through social identity theory (Zagenczyk et al. 2011) We'll also analyze the relationship of job satisfaction/ job dissatisfaction as having mediating role between the relationship of psychological contract (fulfillment/Violations) and voice behavior since job satisfaction is one of most cited and key concepts of organizational behavior studies and still more research is required to be aware of what organizational and individual variables figure out the job satisfaction and dissatisfaction of employees (Viseu et al. 2020). However, specifically, we would focus on our research questions which are "What is the impact of psychological contract fulfillment on employee voice behavior" and "What is the impact on employee voice behavior upon psychological contract violation". The study will be conducted on the banking industry of Pakistan as they are well developed/organized organizations having well-established systems. Therefore, it is less likely that they violate the psychological expectations of their employees. Further, during the period of pandemic COVID-19, since other organizations are mostly closed in Pakistan, banks will remain open and data collection will be easier from banks through acquaintances.

\section{Literature review}

\section{Psychological Contract}

Psychological contracts are found to be based on social exchange perspective (Blau 1964), however, they are considered to have inculcated the sense of both economical as well as social exchanges (Cullinane and Dundon 2006). The work on this construct dates back from the 1960s (Argyris 1960); however, the interest reaches at height during the 1990s until the application of the construct to management theory fully 
emerged (Cullinane and Dundon 2006). Much of the research of this construct came from (Rousseau 1989, 1995). The "psychological contract" refers to the expectations of employer and employee which operate over and above the formal contract of employment" (Argyris 1960) It encompasses beliefs, values, expectations, and aspirations of employer and employee (Smithson and Lewis 2000). These beliefs invoke reciprocal obligations between employee and employer (Rousseau 1989) and form the basis of trust leading towards a mutual cooperation evoking norms of reciprocity (Hui et al. 2004; Mount et al. 2006; Memon et al. 2018). Accordingly, beliefs of employees for long-term obligations (e.g., relational contracts) may invoke an employee to be more engaged in OCB-related activities whereas short-term obligations (e.g., transactional contracts) may decrease this feeling/behavior of employee engagement (Hui et al. 2004). Further, the research shows that fulfillment of psychological contract is related to several employee responses like job satisfaction, trust, in-role and extra-role performances, intention to remain with organization, etc. (Hui et al. 2004).

The authors (Smithson and Lewis 2000) argue that recent definitions of the psychological contract present a bit changed version, where "In return for their loyalty, hard work and commitment, the employee expects to be 'looked after' throughout their employment period." However, this implies homogeneity of expectations and overlooks diversity. Further, the traditional "relational contracts," implicitly depending on trust, loyalty, and job security, are being replaced by "transactional contracts," by virtue of which, employees offer, for instance, long hours and extra work in exchange for high pay and training and development. (Smithson and Lewis 2000)

\section{Voice behavior}

The voice is emphasized to be "positive voice" as acknowledged by NG and Feldman (2011), "expressing change-oriented ideas, opinions, and suggestions intended to improve the situation at work" thus overall representing the kind of voice that brings positive change in organizations and jobs. Whiting et al. (2012) consider "Voice" as a behavior that challenges the status quo having the intention of bringing improvement rather than criticizing any situation and includes such behaviors as speaking up about organizational issues and suggesting changes to standard operating procedures. Researchers have considered voice behavior to be based on the social exchange theory (Blau 1964) representing the reciprocatory behavior of employees against the favors, organization and their supervisors have done to them (Memon et al. 2018) and thus as a norm they do raise their voice intensely (Cropanzano and Mitchell 2005).

Morrison (2011) considers voice behavior, from an employee perspective, as a point of concern for personal safety as his / her behavior may result in bringing up negative consequences due to a person present at a higher post/position. Accordingly, employees withhold their voices due to the fear of injustice from those in a position of power and used the term "defensive silence" and "quiescent silence" for such kind of situation. Thus, voice can bring strain in relationships and reflect negatively upon others.

Whiting et al. (2012)have noticed and emphasized on employee voice behavior which came as the most influential and frequent exercise with the aspect of bringing organizational changes, for instance, identification and correction of organizational inefficiencies, identifying potential opportunities, etc. Liu et al. (2010) describe that due to turbulent market situations and competitiveness, organizations need innovative 
ideas and improved practices; therefore, voice behavior plays a critical role in the organizations. The authors have stressed the importance of leaders' role (transformational leadership) as they motivate their employees and empower them to raise their voice for the betterment of the organizations. Accordingly, several studies reveal the relationship between perceptions of raising voice and the quality of one's relationship with one's boss (Morrison 2011). Further, upward information flow is only possible while the supervisor is interested and values its employees and provides fair consideration to their ideas and suggestion. This behavior of a supervisor transmits a feeling of efficacy and safety of voice (Morrison 2011) while giving psychological empowerment to the employee thus allowing him to raise his voice.

In this study, the authors would focus on two types of voices, i.e., promotive voice and prohibitive voice behaviors which would result from psychological contract fulfillment and violations respectively.

\section{Psychological contract violations}

The authors Bala et al. (2008) argue that when the organizations are not able to fulfill their obligations either intentionally or unintentionally, employees may experience psychological contract breach. Accordingly, contract breach is defined as the "cognitions of an employee that the organization has failed to deliver its obligations" resulting in employee reaction, including feelings of anger and betrayal (i.e., contract violation).

The authors Cullinane and Dundon (2006) argue that the relationship based on social exchange is always problematic, where organizations have to execute reciprocal dealings, in order to maintain the employee trust and employer legitimacy due to the fact that continuous and competitive market pressures, reduction in the cost of production, etc. have forced the organizations to take some tough decisions which lead to employee negativity and decreased reciprocal cooperation and interest in the job and even resistance (Antonaki and Trivellas 2014; Cullinane and Dundon 2006). In this relationship, the breach of the psychological contract occurs, when an employee perceives an imbalance between what was promised and what they actually receive; thus, they consider it inequality of the reciprocal relationship and try to balance this relationship through the reduction of their contribution (Turnley et al. 2003). Further, the literature suggests that psychological contract breach results in a broad range of unconstructive outcomes, including reduced trust in the organization, job dissatisfaction, increased cynicism about organizational life, in general, and increased intent to quit (Antonaki and Trivellas 2014; Turnley et al. 2003; Mount et al. 2006).

\section{Job satisfaction and dissatisfaction}

Job satisfaction and dissatisfaction are the most widely studied and key constructs in organizational behavior literature (Moro et al. 2020; Viseu et al. 2020; Zhou and George 2001) since organizations achieve their desired targets and goals through satisfied employees. Nevertheless, still more research is required to be aware of what organizational and individual variables figure out the job satisfaction and dissatisfaction of employees (Viseu et al. 2020) Satisfied employees are assets to their organizations, portraying amplified physical and psychological health. Dissatisfied employees provide inferior quality of work and physical and psychological health that would negatively manipulate 
the organizational performance (for instance, reduction in the number of customers and negative word of mouth or prohibitive voice behavior) (Viseu et al. 2020).

Job satisfaction can be defined as "the reaction of people who enjoy their work and do it well, revealing characteristics of fulfillment and pride based on a range of elements" (Moro et al. 2020). In this setting, the two main stakeholders interested are the employees themselves and leaders/managers from the organizational end. It is for sure that the managers expect workers to be satisfied and work positively while being psychologically and physically dedicated to their jobs. On the other end, employees' psychological expectations are to be dealt respectfully while fulfilling their psychological expectations. As discussed by Moro et al. (2020) regarding US IT professionals, $13 \%$ of them were discovered to be dissatisfied with their job in 2016 and the reasons were majorly unmet expectations. The literature further suggests that psychological contract breach results in a broad range of unconstructive outcomes, including reduced trust in the organization, job dissatisfaction, increased cynicism about organizational life in general, and increased intent to quit (Antonaki and Trivellas 2014; Turnley et al. 2003; Mount et al. 2006)

\section{Theoretical framework and hypothesis development}

\section{Psychological contract (fulfillment) and voice behavior}

A number of researches have been conducted empirically that demonstrate the relationship of psychological contract fulfillment and work outcomes, for instance, job satisfaction, in-role performance and organizational citizenship behavior (Antonaki and Trivellas 2014; Hui et al. 2004; Turnley et al. 2003), organizational commitment, employee performance, employee contract behavior, and employees' perceived organizational support (Coyle-Shapiro and Kessler 2000; Lee and Varon 2020).

Psychological contract is based on trust (Hui et al. 2004; Rousseau 1989) which meeting of expectations enhances employees' commitment, productivity, satisfaction, OCB, etc. (Turnley et al. 2003). Literature has discussed more the terms of commitment and OCB (Markos and Sridevi 2010) while showing the affiliation of an employee. Further, the literature considers voice behavior as extra-role behavior just like OCB (Liu et al. 2010) representing the reciprocatory behavior of employees in response to the favors that organization and their supervisors have done to them, and thus, as a norm, they do raise their voice intensely (Cropanzano and Mitchell 2005)

A number of antecedents of OCB have been reported in the literature which includes job satisfaction, commitment, and perceived organizational support (Coyle-Shapiro and Kessler 2000) where overall job satisfaction refers to an employee's evaluation of his/ her work and his/her working conditions and the degree to which job needs are fulfilled and how much of this fulfillment is perceived by an employee (Rayton and Yalabik 2014). It comprises of attitude instead of emotion to the extent that it is an "evaluative judgment" of self-work and "affective-laden" vulnerable to organizational changes (Antonaki and Trivellas 2014). Thus, the employee, while getting satisfied job conditions and rewards as per expectations, reciprocates in a positive manner through positive attitudes and behaviors towards job and organization (Rayton and Yalabik 2014)Accordingly, several researches consider the mediating role of job satisfaction 
between the relationship of Psychological Contract and working outcomes of employees, for instance, OCB, organizational commitment, work engagement, etc. (Antonaki and Trivellas 2014; Rayton and Yalabik 2014; Turnley and Feldman 2000).

Further, the research shows that the perceptions of "Empowerment" are strongly associated with job satisfaction and performance variables, where both organizations and employees get benefited (Arnold et al. 2000; Robert et al. 2000). This sense of empowerment invokes and motivates an employee to raise his voice to be heard for the decision-making purposes and for the betterment of the organization (Morrison 2011). Therefore, it is more likely that upon fulfillment of psychological contract, the employee gets satisfied and in exchange raises his voice for the betterment of the organization since the antecedent of positive voice behavior is job satisfaction (Nikolaou et al. 2008) Hence, we formulate our hypothesis as follows:

\section{H1a: Psychological contract (fulfillment) influences job satisfaction positively. H1b: Job satisfaction mediates the relationship between psychological con- tract (fulfillment) and voice behavior (promotive).}

\section{Psychological contract (violations) and voice behavior}

The authors Coyle-Shapiro and Kessler (2000) describe that there exist some reasons in the mind of the employee for the perceived contract violations which are either inability or unwillingness of the employer to fulfill obligations of the employees. The third reason could be that the employer does not consider or perceive it as an obligation. Thus, a psychological contract violation arises from unmet expectations about the delivery of a promise/resource (Rayton and Yalabik 2014).

However, the research has shown negative consequences of the psychological contract breach with some incidents of retaliatory behavior in the form of theft and sabotage (Coyle-Shapiro and Kessler 2000). The victim gets a feeling of betrayal and deeper psychological distress which not only produces unmet expectations instead leads to job dissatisfaction (Rousseau 1989). In fact, the psychological contract violations are thought to produce more than just "unmet expectations" like previous researches because it demolishes the foundation of this relationship on the basis of which the relationship was established, i.e., Trust, between the employee and the employer (Turnley and Feldman 2000). Several researches suggest that violations of psychological contract develop the feeling of inequality leading towards the job dissatisfaction, where a feeling of resentment and mistrust is also reported (Rousseau 1989).

One step ahead of these researches, the authors Turnley and Feldman (2000) conducted a research to find the relationship between psychological contract violations and employees' contribution to the organization, for instance, OCB, through the mediating role of job satisfaction where the violations are likely to create the sense of job dissatisfaction which will in turn lead to decreased employee contributions towards the organization (Turnley and Feldman 2000).

The authors Antonaki and Trivellas (2014) posits that it is due to the norm of reciprocity that an employee contributes negatively or decreases their efforts for the organization, adopting the negative attitude of the organization. In order to balance the reciprocatory relationship, an employee constantly evaluates the organization's 
behavior with regard to its contributions, but due to continuous neglect/violations, these negative attitudes and behaviors arise (Antonaki and Trivellas 2014).

The research has documented very well the outcomes as well as behaviors of psychological contract breach (Turnley and Feldman 2000) which could be an intention to leave the organization, neglect of in-role responsibilities, whereas as OCB will be negatively related to psychological contract violations (Turnley and Feldman 2000).

The authors of this article accordingly hypothesize that in developing countries like Pakistan, the relationship of psychological contract breach/violations would be even worse and thus would have a negative relationship with voice behavior through the mediation of job dissatisfaction.

\section{H2a: Psychological contract (violation) influences job dissatisfaction.}

\section{H2b: Job dissatisfaction mediates the relationship between psychological contract (violation) and voice behavior (prohibitive).}

\section{Methodology}

\section{Sample and procedure}

The study is based on a cross-sectional survey administered through a self-reported questionnaire, to be filled by employees, measuring the relationship between psychological contract (fulfillment/violations) and employee voice behavior. We have focused on the employees of two private banks of Pakistan having multiple branches. These banks operate almost all over the country; however, data was collected from their 8 branches located in the city of Lahore. We have used the convenience sampling method for the collection of data. However, the time lag technique has been used to avoid common method bias, and accordingly, temporal and psychological separations of our variables were used (O.Farooq et al. 2017). This was achieved by dividing our questionnaire sheets into two parts. One sheet consisted of variables of psychological contract (fulfillment/violations) and job satisfaction/dissatisfaction whereas the other booklet consisted of voice behavior (promotive/prohibitive) and these were given to the employees after the gap of 15-20 days. We requested our acquaintances (managers/ supervisors) to help us in collecting the data from their employees. The questionnaire was accompanied by a cover letter mentioning the purpose of the study and approx 120 employees were handed over and asked to fill out the questionnaire for the particular research. In the current study, the researchers have selected sample size based on GPower (Cohen 1988) whereby the parameters were effect size $f^{2}=0.15, \alpha$ err prob $=$ 0.05 (Faul et al. 2007) having 2 number of predictors for the multiple linear regression model, and thus, we got the maximum sample size of 89 in the two-tail and 74 in the one-tail test. So, we opted for the maximum sample size, i.e., 89. We targeted 120 employees through our acquaintances whereas out of 120, 89 responses were received as complete with all aspects and were used for the data analysis purposes. The frequency of male was $66(74 \%)$ and female was $23(26 \%)$. Seventy-five (84\%) employees out of 89 are having experience of 3 or more years showing that they have experienced the psychological commitment fulfillment/violations and its impact can be 
measured on these employees through voice behavior measurement. Data of the respondents are presented in Table 1.

\section{Tools and measurements}

A number of tools have been adapted to test the model whose validity and reliability have already been established. For instance, the degree of psychological contract fulfillment and violation was assessed with a multi-item measure developed by Turnley and Feldman (2000). The measure is comprised of 16 items tapping the typical dimensions of the employment relationship studied in previous research (Robinson and Rousseau 1994; Rousseau 1989), for instance, salary, pay raises, bonuses, training, advancement opportunities, career development, overall benefits, retirement benefits, health care benefits, decision-making input, job responsibility, job challenge, feedback on job performance, supervisory support, organizational support, and job security.

Accordingly, respondents were asked to indicate how the amount of each aspect they had actually received compared with the amount that the organization had committed to provide them. Responses were made on a five-point Likert scale scored as follows: 1 (receive much more than promised); 2 (receive more than promised); 3 (receive about the same as promised); 4 (receive less than promised); and5 (receive much less than promised). The higher the score, the greater the magnitude of psychological contract violation it represents. The authors Turnley and Feldman (2000) noted that assessing the degree of psychological contract violation in this way takes into account the full range of variance possible on these items, from over-fulfillment

Table 1 Demographic characteristic of the respondents

\begin{tabular}{lll}
\hline Demographics & & Frequency \\
\hline Age & $18-28$ & 16 \\
& $29-40$ & 45 \\
Gender & $41-55$ & 28 \\
& Male & 66 \\
Service tenure (years) & Female & 23 \\
& 1 & 6 \\
& 2 & 8 \\
Qualification & 3 & 16 \\
& 4 & 20 \\
& 5 & 24 \\
& 6 & 15 \\
Management level & Below Bachelors & 9 \\
& Bachelors & 34 \\
& Masters & 27 \\
& MS/Mphil & 17 \\
& Middle/lower management & 44 \\
& Supervisor & 8 \\
& Non-management lower level staff & 37 \\
\hline
\end{tabular}


(receiving more than promised) to under-fulfillment (receiving less than promised). Thus, this single scale can be used to determine both the psychological contract fulfillment and violations.

We used a five-item perception questionnaire, developed by Hackman and Oldham (1975) and adopted from (Zhang et al. 2014), to measure job satisfaction. Further, the job dissatisfaction was measured through the depiction of lesser scores of same items thus the lesser the score; the greater will be job dissatisfaction. A sample item is: "Overall, I am very satisfied with this job" and the questionnaire has a Cronbach's alpha of .851 .

To measure employees' voice behavior, we have adopted the 11-item questionnaire developed by Liang et al. (2012) and adopted from (Zhang et al. 2014). It consists of five items to evaluate promotive voice behavior, e.g., "Proactively voice your constructive suggestions that can help the unit reach its goals," and six items to measure prohibitive voice behavior, e.g., "Voice your opinion on things that might affect efficiency in the work unit,even if it is embarrassing." The questionnaire has a Cronbach's alpha of .923. The items were rated on a 5-point Likert scale with response options ranging from 1 = strongly disagree to $5=$ strongly agree.

Further, we shall consider gender, age, tenure, and educational level as control variables as these may influence employees' extra-role behaviors (Zhang et al. 2014). We have adapted the instrument and discussed the adapted tool with 2 university professors/experts in the organizational behavior field to identify any potential problems associated with adaptation. As per recommendations of experts, little changes were made, and then, the tool was used for the empirical assessment.

\section{Data analysis}

The collected data were analyzed by using SPSS and partial least squares structural equation modelling (PLS-SEM) via Smart PLS 3.0. Data was entered through SPSS version 22 and initial tests of data normality, correlation, etc. were tested, later model /hypothesis testing was performed through PLS 3, i.e., the SPSS was used for descriptive statistics, and the PLS was utilized for causal relationship testing (regression-based technique). The aim is to come across a detailed analysis of the relationship between psychological contract (fulfillment/violations) and voice behavior through the mediating variables. Further, the mediating variable, job satisfaction/job dissatisfaction, will be analyzed in depth so as to test the real/actual mediating effects between the relationship of both independent and dependent variables and while the correct model specification cannot be ensured, it led us to the application of Smart PLS (Wong 2013).

\section{Findings and results}

\section{Descriptive statistics}

Table 2 indicates that voice behavior negative (mean $=3.69, \mathrm{SD}=.57$ ) has the highest skewness (2.02) as well as kurtosis values which are 1.41. Further, job satisfaction (mean $=3.56, \mathrm{SD}=.66)$ has the lowest skewness which is negative as well $(-0.384)$. The kurtosis for all the items is positive except psychological contract fulfillment. Since 
Table 2 Descriptive statistics

\begin{tabular}{lllll}
\hline Construct & Mean & Std. deviation & Skewness & Kurtosis \\
\hline Voice behavior (positive) & 3.58 & 0.69 & -0.196 & 0.502 \\
Voice behavior (prohibitive) & 3.69 & 0.57 & 2.02 & 1.417 \\
Job satisfaction & 3.56 & 0.66 & -0.384 & 0.604 \\
Job dissatisfaction & 3.46 & 0.48 & -0.234 & 0.402 \\
Psychological contract fulfillment & 3.39 & 0.60 & -0.134 & -0.240 \\
Psychological contract violations & 3.48 & 0.64 & -0.324 & 1.980 \\
\hline
\end{tabular}

all the constructs are within the range of \pm 3.5 , therefore, it can be assumed that the data has a normal tendency (Hair et al. 2010).

\section{Validity and reliability tests}

Table 3 presents the validity and reliability of all constructs included in our study, i.e., outer model as per the recommendations of Hair et al (2017), i.e., through the measurement of internal consistency reliability, convergent validity, and discriminant validity. Table 3 shows the values of construct reliability (CR) and average variance extracted (AVE) where CR is an established measure of internal consistency reliability (Hair et al. 2017); however, AVE and outer loadings represent convergent validity of our constructs (Hair et al. 2017). The CR values indicate that construct reliability of all variables is greater than 0.7 which is the acceptable standard in terms of internal consistency. Moreover, average variance extracted values are greater than 0.5 for each construct, thus indicating that data is convergent valid.

In addition to this, Table 4 presents the discriminant validity of data through the method given by Fornell and Larcker (1981). The values in diagonal represent the square root of average variance extracted values, whereas the remaining values represent the correlations between the variables. All diagonal average variance extracted values are greater than the correlations, which indicate the existence of discriminant validity of data. Moreover, to prove discriminant validity, we also checked the crossloadings of all items. The cross-loadings were appropriate and above 0.7 for each relevant item of a specific variable.

Table 3 Construct reliability and convergent validity through AVE

\begin{tabular}{llll}
\hline Constructs & No. of items & Construct reliability & Average variance extracted (AVE) \\
\hline 1. Psy.contract (fulfillment) & 14 & 0.854 & 0.642 \\
2. Voice behavior (positive) & 4 & 0.889 & 0.611 \\
3.Job satisfaction & 5 & 0.78 & 0.618 \\
4.Job dissatisfaction & 5 & 0.78 & 0.618 \\
5. Psy.contract (violations) & 14 & 0.854 & 0.642 \\
6. Voice behavior (prohibitive) & 5 & 0.843 & 0.724 \\
\hline
\end{tabular}


Table 4 Discriminant validity

\begin{tabular}{lllllll}
\hline & 1 & 2 & 3 & 4 & 5 & 6 \\
\hline Psy.contract (fulfillment) & 0.75 & & & & & \\
VB (positive) & 0.134 & 0.715 & & & & \\
Psy contract (violations) & 0.27 & 0.016 & 0.715 & & & \\
VB (prohibitive) & 0.253 & 0.075 & 0.582 & 0.741 & & \\
Job satisfaction & 0.422 & 0.177 & 0.525 & 0.502 & 0.748 & \\
Job dissatisfaction & 0.463 & 0.083 & 0.624 & 0.424 & 0.426 & 0.756 \\
\hline
\end{tabular}

Furthermore, after checking the reliability and validity of the outer model, we examined whether any multicollinearity issue exists in the data. It was examined for both inner and outer models through variance inflation factor (VIF) values.

The rule states that variance inflation factor values must be below 5 , indicating no issue of multicollinearity; values for our model lie between 1.0 and 3.5 that are less than the threshold 5 (Cohen et al. 2013). Thus, the risk of any problem related with multicollinearity is not present. After that, we conducted regression tests for the inner model. Results indicate that the overall model fitness is $34 \%$ and $36 \%$, respectively, which is represented through the value of adjusted $R$ square, depicting good model fit. Moreover, to the above test, another test was performed for calculating the $F^{2}$ ( $F$ square values which represent the contribution of individual variables to adjusted $R$ square. $F$ square values for each variable should be at least 0.02 for minimum contribution, greater than 0.15 for moderate contribution, and greater than 0.35 for high contribution (Cohen et al. 2013). Our data results showed that $F$ square values for all variables were above the threshold value, which means that all variables contributed to $R$ square.

\section{Path coefficients}

Table 5 summarizes the acceptance of hypotheses and our overall regression results. the bootstrapping method was used with 5000 re-samples and $t$ test was employed. In addition, the $Q$ square (Geisser criterion value) is 0.14 and 0.12 , respectively, i.e., greater than 0 being its minimum value, which implies that the latent variables in the model have high predictive ability (Yi et al. 2011). The results have been reported in two models for discriminating the impact of psychological contract fulfillment and violation pathway as well as the results of job satisfaction and dissatisfaction.

Table 5 clearly shows all the regression (direct and indirect) paths, their significance levels, and standard deviation values of all variables. The first path (model 1) as per our first hypothesis is from psychological contract fulfillment to job satisfaction (Psy.conrtract fulfill $>$ job satisfaction), i.e., direct relationship, which has been proved as positive and significant at $p<0.001$ (H1 a accepted). Likewise, to prove mediation of job satisfaction between psychological contract fulfillment and employee voice behavior, we should see two paths (one from job satisfaction $>$ voice behavior, and the other from psych.contract fulfill $>$ job satisfaction $>$ positive voice behavior). Both these relationships are significantly positive at $p<0.05$ and $p<0.01$ respectively; thus, mediation of job satisfaction between psychological contract fulfillment and positive 
Table 5 PLS structural model results

\begin{tabular}{|c|c|c|c|c|c|c|}
\hline & Coefficients & $\begin{array}{l}\text { Standard } \\
\text { deviation } \\
\text { (STDEV) }\end{array}$ & $T$ statistics & $P$ values & $2.50 \%$ & $97.50 \%$ \\
\hline \multicolumn{7}{|l|}{ Model 1} \\
\hline $\begin{array}{l}\text { Psy.contract fulfill }>\text { job } \\
\text { satisfaction }\end{array}$ & 0.240 & 0.044 & 6.086 & 0.00 & 0.188 & 0.328 \\
\hline $\begin{array}{l}\text { Job satisfaction }>\text { positive } \\
\text { voice behavior }\end{array}$ & 0.239 & 0.072 & 5.306 & 0.03 & 0.321 & 0.246 \\
\hline $\begin{array}{l}\text { Psy.contract }>\text { job satisfaction }> \\
\text { positive voice behavior }\end{array}$ & -0.278 & 0.054 & 4.418 & 0.00 & -0.317 & -0.129 \\
\hline \multicolumn{7}{|l|}{ Model 2} \\
\hline $\begin{array}{l}\text { Psy.contract violate }>\text { job } \\
\text { dissatisfaction }\end{array}$ & 0.219 & 0.079 & 3.46 & 0.01 & 0.246 & 0.202 \\
\hline $\begin{array}{l}\text { Job dissatisfaction }>\text { negative } \\
\text { voice behavior }\end{array}$ & 0.220 & 0.049 & 4.329 & 0.02 & 0.031 & 0.216 \\
\hline $\begin{array}{l}\text { Psy.contract violate }>\text { job } \\
\text { dissatisfaction }>\text { negative } \\
\text { voice behavior }\end{array}$ & -0.272 & 0.049 & 4.328 & 0.00 & -0.207 & -0.129 \\
\hline
\end{tabular}

voice behavior is proven ( $\mathrm{H} 1 \mathrm{~b}$ accepted). Moreover, we tested the mediation of job dissatisfaction between psychological contract violation and employee negative voice behavior (model 2). Again we should see two paths (one from job dissatisfaction > voice behavior, and other from psych.contract violation $>$ job dissatisfaction $>$ negative voice behavior). Both these relationships are significantly positive at $p<0.05$ and $p<$ 0.01 respectively proving our hypotheses $\mathrm{H} 2 \mathrm{a}$ and $\mathrm{H} 2 \mathrm{~b}$. Hence, our entire hypotheses were accepted and have shown a significant impact on our dependent variable. This also proves the strength of our structural model as well as model fitness.

\section{Discussion and theoretical implications}

The study investigates the impact of psychological contract fulfillment/violations on employee voice behavior working in a banking sector of Pakistan. Further, we explored whether job satisfaction/dissatisfaction acts as a mediator between the relationships of psychological contract fulfillment/violation respectively.

Unlike previous studies which incorporated the social identity theory (Zagenczyk et al. 2011) for employee voice behavior, our study employed the social exchange theory to test the above-discussed relationships. Results revealed numerous important findings and thus contributed to the theory in multiple ways. Most of the previous studies have measured the performance as compared with the employee's engagement behavior (Rothmann and Coetzer 2003) or psychological contract violation having a relationship with employee behavior through the mediation of job dissatisfaction and unmet expectations (Turnley and Feldman 2000)

Contrary to previous studies which have focused on other constructs for measuring the effect of psychological contract fulfillment/violations, for instance, employee 
behaviors, i.e., intention to quit or OCB (Turnley and Feldman 2000), organizational identification and psychological contracts (Zagenczyk et al. 2011), and performance appraisal and voice behavior (Zhang et al. 2014), our study has focused on the broader construct of employee voice behavior, i.e., both positive and negative. Also, the construct of psychological contract has been measured as "fulfillment and violation" in both areas, whereas previous studies have mostly not conducted empirical studies by taking both dimensions of this construct.

Our results of hypothesis 1 and hypothesis 2 are consistent with other studies on psychological contract and voice behavior (Zhang et al. 2014; Turnley and Feldman 2000) presenting that taking employee benefit initiatives and showing care and concern for employees lead towards the development of trust and then getting employees satisfied (Zagenczyk et al. 2011). It is, however, found that due to a lack of support for employees in human resource-related activities, internal CSR activities and employee-related activities create job dissatisfaction or the feeling of being deceived and psychologically deprived. This result of ours is also consistent with other studies conducted in Pakistan (Memon et al, 2020; O.Farooq et al. 2013,; M.Farooq et al, 2014) This shows that employees in the Pakistani environment are more concerned for activities which are performed directly for them instead of other employees or external stakeholders, probably due to having low economic status and being developing nation.

The results are consistent with previous studies investigating the direct outcomes of psychological contract violations (Turnley and Feldman 2000; Knights and Kennedy 2005) since psychological contract violations have a detrimental impact on employee behavior. Specifically, psychological contract violations direct employees to deliberately neglect their in-role job duties and responsibilities, rather than spread negativity about the organization causing disparity and bad image/reputation of the organization (Viseu et al. 2020).

This empirically tested model within the context of Pakistan provides important implications for researchers as well as practitioners. Through this study, the emphasis has been drawn on the relationship between psychological contract fulfillment/violations and employee voice behavior through social exchange perspective and considering "job satisfaction/dissatisfaction" as the critical element and it has been proposed that psychological contract fulfillment plays a major part in gaining employees' trust over organizations as well as leaders. Further, it is proposed that employees may perceive psychological contract fulfillment good for the identification purposes.

The results of our study are encouraging for those interested in pursuing further research on psychological contract fulfillment/violations. Since psychological contract fulfillment increase employees' satisfaction and trust level of their organizations, therefore other employee behaviors, not studied by the current study, can be analyzed while including the control variables of our research in their results. Similarly, psychological contract violations which may result in job dissatisfaction and employees' decrease in trust on the organization can be analyzed accordingly (Moro et al. 2020). As employee decrease in salaries especially in the difficult times of the coronavirus lockdown 2020, layoffs and reorganizations continue to occur, we expect that employment relationship continues to undergo a major transformation. Thus, the significance of understanding psychological contract violations will continue to be an important issue for researchers and practitioners equally. This study helps to explain why psychological contract violations have the negative effects that they do. 
Unfortunately, the human resource practitioners in Pakistan are still unable to implement human resource interventions in its true sense resulting in poor employee practices and, thus, gaining lesser support from their employees. Therefore, this study encourages practitioners to experience new methodologies of conveying the feelings of concern, care, and protection through various human resource interventions, supervisor/leader's mentoring behaviors, and communication system being the most affecting drivers of employee engagement leading towards employee performance as well as gaining the trust of employees (Memon et al, 2020; Bedarkar and Pandita 2014). Further, employees may be involved in the goal setting process then suggesting him/ her for improvement, if required, during review sessions. Similarly, training and development activities like on-the-job training, rotations, educational opportunities, and involvement in the decision-making process will surely develop the sense of shared ownership (Vlachos 2009; Knezović et al. 2020). Accordingly, employees will perform reciprocally and will go beyond their work obligations provided they receive the sense of meaningfulness, safety, and availability as proposed by Kahn (1990).

\section{Research limitations}

As this particular study is only within the context of Pakistan (a developing country), with a limited number of respondents, therefore the study cannot be generalized to developed settings, where the results may vary with different contexts and countries. However, the same may be extended to the other Asian countries, especially developing South Asian countries with similar infrastructure and economic conditions. Therefore, the authors propose that surveys or interviews with the co-workers may be carried out to know the exact reaction and dealing in a practical situation for testing how individuals with different personality traits behave under those circumstances and control the situation. Further, future researchers may test the same especially in different demographic conditions, for instance, age, race, gender, etc. in different cultural settings as individual personality traits vary with the variance of cultural effects as well (Kular et al. 2008). Further, different models may be tested apart from the big five-factor model for measuring especially the relationship between psychological contract fulfillment/violations and employee voice behavior.

\section{Conclusion and managerial implications}

The study presented the synthesis of literature and then empirically testing while portraying the importance of psychological affiliation of an individual with the organization through the psychological contracts. Our study concluded that employees demonstrate positive voice behavior in reciprocation, when they feel psychologically satisfied and perceive a sense of organizational support through the fulfillment of psychological contracts (Zulfiqar et al. 2019).

However, this phenomenon is so much important for the satisfaction and obtaining employee's commitment as well as positive work behavior that if employees receive negative indication, i.e., psychological contract breach, then this would lead to job dissatisfaction and disparity in employees. Further, it develops in them a feeling of 
mistrust regarding the organization while being deceived through psychological contract violations and thus resulting in negative voice behavior as well as other negative work behaviors (Turnley and Feldman 2000; Moro et al. 2020; Viseu et al. 2020).

The stance of the current study is all about how employee voice can be most effective in carrying out organizational improvement and how it builds an interpersonal relationship between managers and employees. The ground of the current study shows that organizations can have tremendous benefits by voice behavior if employees get psychologically satisfied by organizations (Viseu et al. 2020). In light of current study, the authors would like to recommend a few tactics such as organization should also consider the nature of voice that is being, or feedback, expressed through voice. The construct of voice does not only comprise to give ideas, opinions, and suggestions but also to comprehend its formulation and operationalization process (Elizabeth Wolfe Morrison and Milliken 2003; Ghani and Memon 2020). There should be much concern on the fluctuation of voice and how it treats the organization processes. Further, all these benefits of voice behavior can be taken by the organization only if the employee feels at ease and satisfied from his/her job. In this regard, organizations should make those kinds of commitments which can really be fulfilled rather than just claims and taking employees to the dreamworld resulting in violation of psychological contract.

\section{References}

Antonaki, X.-E., \& Trivellas, P. (2014). Psychological contract breach and organizational commitment in the greek banking sector: the mediation effect of job satisfaction. Procedia-Social and Behavioral Sciences, $148,354-361$.

Argyris, C. (1960). Understanding organizational behavior. Homewood: Dorsey Press.

Arnold, J. A., Arad, S., Rhoades, J. A., \& Drasgow, F. (2000). The empowering leadership questionnaire:the construction and validation of a new scale for measuring leader behaviors. Journal of Organizational Behavior, 21, 249-269.

Bala, P. M., Lange, A. H. D., Jansen, P. G. W., \& Velde, M. E. G. V. D. (2008). Psychological contract breach and job attitudes: a meta-analysis of age as a moderator. Journal of Vocational Behavior, 72, 143-158.

Bartodziej, C. J. (2017). The Concept Industry 4.0, BestMasters. Springer Fachmedien Wiesbaden GmbH. https://doi.org/10.1007/978-3-658-16502-4_1.

Bedarkar, M., \& Pandita, D. (2014). A study on the drivers of employee engagement impacting employee performance. Procedia - Social and Behavioral Sciences, 133, 106-115.

Blau, P. M. (1964). Exchange and power in social life. New York: Wiley.

Cohen, J. (1988). Statistical Power analysis for the behavioral sciences. Mahwah: Lawrence Erlbaum.

Cohen, J., Cohen, P., West, S. G., \& Aiken, L. S. (2013). Applied multiple regression/correlation analysis for the behavioral sciences. Routledge.

Coyle-Shapiro, J. A.-M., \& Kessler, I. (2000). Consequences of the psychological contract for the employment relationship: a large scale survey. The Journal of Management Studies, 37(7), 904-930.

Cropanzano, R., \& Mitchell, M. S. (2005). Social exchange theory: an interdisciplinary review. Journal of Management, 31(6), 874-900.

Cullinane, N., \& Dundon, T. (2006). The psychological contract: a critical review. International Journal of Management Reviews, 8(2), 113-129.

Detert, J. R., \& Burris, E. R. (2007). Leadership behavior and employee voice: Is the door really open? Academy of Management Journal, 50, 869-884.

Eisenberger, R., Huntington, R., Hutchison, S., \& Sowa, D. (1986). Perceived organizational support. Journal of Applied Psychology, 71(3), 500-507.

Engemann, K. N., \& Scott, C. W. (2020). Voice in safety-oriented organizations: examining the intersection of hierarchical and mindful social contexts. Human Resource Management Review, 30(1), 100650. 
Farooq, O., Payaud, M., Merunka, D., \& Valette-Florence, P. (2013). The Impact of corporate social responsibility on organizational commitment: exploring multiple mediation mechanisms. Journal of Business Ethics, 125, 563-580. https://doi.org/10.1007/s10551-013-1928-3.

Farooq, M., Farooq, O., \& Jasimuddin, S. M. (2014). Employees response to corporate social responsibility: exploring the role of employees' collectivist orientation. European Management Journal, 32, 916-927. https://doi.org/10.1016/j.emj.2014.03.002.

Farooq, O., Rupp, D. E., \& Farooq, M. (2017). The multiple pathways through which internal and external corporate social responsibility influence organizational identification and multifoci outcomes: The moderating role of cultural and social orientations. Academy of Management Journal, 60(3), 954-985.

Faul, F., Erdfelder, E., Lang, A. G., \& Buchner, A. (2007). G* Power 3: a flexible statistical power analysis program for the social, behavioral, and biomedical sciences. Behavior Research Methods, 39(2), 175-191.

Fornell, C., \& Larcker, D. F. (1981). Evaluating structural equation models with unobservable variables and measurement error. Journal of marketing research, 18(1), 39-50.

Ghani, B., \& Memon, K. R. (2020). The HR practices and organizational citizenship behavior. International Journal of Management Sciences and Business Research, 9(1), 43-52.

Hair Jr., J. F., Black, W. C., Babin, B. J., Anderson, R. E., \& Tatham, R. L. (2010). SEM: an introduction. Multivariate data analysis: A global perspective, 5(6), 629-686.

Hair, J.F., Hult, G.T.M., Ringle, C.M. \& Sarstedt, M. (2017). A Primer on Partial Least Squares Structural Equation Modeling (PLS-SEM), 2nd ed., Sage, Thousand Oaks, CA.

Hackman, J. R., \& Oldham, G. R. (1975). Development of the job diagnostic survey. Journal of Applied Psychology, 60(159-170).

Hui, C., Lee, C., \& Rousseau, D. M. (2004). Psychological contract and organizational citizenship behavior in China: investigating generalizability and instrumentality. Journal of Applied Psychology, 89(2), 311-321.

Kahn, W. A. (1990). Psychological conditions of personal engagement and disengagement at work. Academy of Management Journal, 33(4), 692-724.

Knezović, E., Bušatlić, S., \& Riđić, O. (2020). Strategic human resource management in small and medium enterprises. International Journal of Human Resources Development and Management, 20(2), 114-139.

Knights, J. A., \& Kennedy, B. J. (2005). Psychological contract violation: impacts on job satisfaction and organizational commitment among Australian senior public servants. Applied HRM Research, 10(2), 57-72.

Kular, S., Gatenby, M., Rees, C., Soane, E., \& Truss, K. (2008). Employee engagement: a literature review. Kingston University Working Paper Series, 19.

Lee, J., \& Varon, A. L. (2020). Employee exit, voice, loyalty, and neglect in response to dissatisfying organizational situations: it depends on supervisory relationship quality. International Journal of Business Communication, 57(1), 30-51.

LePine, J. A., \& Dyne, L. V. (1998). Predicting voice behavior in work groups. Journal of Applied Psychology, 83(6), 853-868.

LePine, J. A., \& Van Dyne, L. (2001). Voice and cooperative behavior as contrasting forms of contextual performance: evidence of differential relationships with big five personality characteristics and cognitive ability. Journal of Applied Psychology, 86(2), 326-336.

Liang, J., Farh, C. I. C., \& Farh, J. L. (2012). Psychological antecedents of promotive and prohibitive voice: A two-wave examination. Academy of Management Journal, 55(71-92)

Liu, W., Zhu, R., \& Yang, Y. (2010). I warn you because I like you: voice behavior, employee identifications, and transformational leadership. The Leadership Quarterly, 21, 189-202.

Markos, S., \& Sridevi, M. S. (2010). Employee engagement: the key to improving performance. International Journal of Business and Management, 5(12), 89-96.

Memon, K. R. (2014). Effects of leadership styles on employee performance: Integrating the mediating role of culture, gender and moderating role of communication. International Journal of Management Sciences and Business Research, 3(7), 63-80.

Memon, K. R, Ghani, B, Khalid, S (2020). The relationship between corporate social responsibility and employee engagement-A social exchange perspective. International journal of business science and applied management, 15(1), 1-16

Memon, K. R., Ghani, B., \& Kazi, A. A. (2018). Restructuring the relationship between performance management and employee engagement. Pakistan Business Review, 20(1).

Morrison, E. W., \& Milliken, F. J. (2003). Speaking up, remaining silent: The dynamics of voice and silence in organizations. Journal of Management Studies, 40(6), 1353-1358

Moro, S., Ramos, R. F., \& Rita, P. (2020). What drives job satisfaction in IT companies? International Journal of Productivity and Performance Management, ahead-of-print. https://doi.org/10.1108/IJPPM03-2019-0124. 
Morrison, E. W. (2011). Employee voice behavior: integration and directions for future research. The Academy of Management Annals, 5(1), 373-412.

Mount, M., Ilies, R., \& Johnson, E. (2006). Relationship of personality traits and counterproductive work behaviors: the mediating effects of job satisfaction. Personnel Pscyhology, 59(599-622).

Ng, T. W. H., \& Feldman, D. C. (2011). Employee voice behavior: a meta analytic test of the conservation of resources framework. Journal of Organizational Behavior, 33, 216-234.

Nikolaou, I., Vakola, M., \& Bourantas, D. (2008). Who speaks up at work? Dispositional influences on employees' voice behavior. Personnel Review, 37(6), 666-679.

O'Donohue, W., \& Sheehan, C. (2007). The psychological contract of knowledge workers. Journal of Knowledge Management, 11(2), 73-82.

Premeaux, S. F., \& Bedeian, A. G. (2003). Breaking the silence: the moderating effects of self-monitoring in predicting speaking up in the workplace. Journal of Management Studies, 40, 1537-1562.

Raub, S., \& Robert, C. (2012). Empowerment, organizational commitment, and voice behavior in the hospitality industry: evidence from a multinational sample. Cornell Hospitality Quarterly, 54, 136.

Rayton, B. A., \& Yalabik, Z. Y. (2014). Work engagement, psychological contract breach and job satisfaction. The International Journal of Human Resource Management, 25, 2382-2400. https://doi.org/10.1080/ 09585192.2013 .876440 .

Robert, C., Probst, T. M., Martocchio, J. J., Drasgow, F., \& Lawler, J. J. (2000). Empowerment and continuous improvement in the United States, Mexico, Poland, and India: predicting fit on the basis of the dimensions of power distance and individualism. Journal of Applied Psychology, 85(5), 643-658.

Robinson, S. L., \& Rousseau, D. M. (1994). Violating the psychological contract: not the exception but the norm. Journal of Organizational Behaviour, 15, 245-259.

Rothmann, S., \& Coetzer, E. P. (2003). The big five personality dimensions and job performance. SA Journal of Industrial Psychology, 29(1), 68-74.

Rousseau, D. M. (1989). Psychological and implied contracts in organizations. Employee Responsibilities and Rights Journal, 2, 121-139.

Rousseau, D. M. (1995). Psychological contracts in organizations. Understanding written and unwritten agreements. Thousand Oaks: Sage.

Smithson, J., \& Lewis, S. (2000). Is job insecurity changing the psychological contract? Personnel Review, 29(6), 680-702.

Turnley, W. H., \& Feldman, D. C. (2000). Re-examining the effects of psychological contract violations: unmet expectations and job dissatisfaction as mediators. Journal of Organizational Behavior, 21, 25-42.

Turnley, W. H., Bolino, M. C., Lester, S. W., \& Bloodgood, J. M. (2003). The impact of psychological contract fulfillment on the performance of in-role and organizational citizenship behaviors. Journal of Management, 29(2), 187-206.

Viseu, J., Pinto, P., Borralha, S., \& de Jesus, S. N. (2020). Role of individual and organizational variables as predictors of job satisfaction among hotel employees. Tourism and Hospitality Research, 0(0), 1-15.

Vlachos, I. P. (2009). The effects of human resource practices on firm growth. International Journal of Business Science and Applied Management, 4(2), 17-34

Wayne, S. J., Shore, L. M., \& Liden, R. C. (1997). Perceived Organizational support and leader-member exchange: a social exchange perspective. Academy of Management Journal, 40(1), 82-111.

Whiting, S. W., Maynes, T. D., Podsakoff, N. P., \& Podsakoff, P. M. (2012). Effects of message, source, and context on evaluations of employee voice behavior. Journal of Applied Psychology, 97(1), 159-182.

Wong, K. K. (2013). Partial least squares structural equation modeling (PLS-SEM) techniques using SmartPLS. Marketing Bulletin, 24.

Yi, Y., Nataraajan, R., \& Gong, T. (2011). Customer participation and citizenship behavioral influences on employee performance, satisfaction, commitment, and turnover intention. Journal of Business Research, 64(1), 87-95.

Zagenczyk, T. J., Gibney, R., Few, W. T., \& Scott, K. L. (2011). Psychological contracts and organizational identification: the mediating effect of perceived organizational support. Journal of Labor Research, 32(3), $254-281$.

Zhang, X., Hu, B., \& Qiu, M. (2014). Job satisfaction as a mediator in the relationship between performance appraisal and voice behavior. Social Behavior and Personality, 42(8), 1315-1324.

Zhou, J., \& George, J. M. (2001). When job dissatisfaction leads to creativity: encouraging the expression of voice. Academy of Management Journal, 44(4), 682-696.

Zulfiqar, S., Sadaf, R., Popp, J., Vveinhardt, J., \& Máté, D. (2019). An examination of corporate social responsibility and employee behavior: the case of Pakistan. Sustainability, 11(13), 3515.

Publisher's note Springer Nature remains neutral with regard to jurisdictional claims in published maps and institutional affiliations. 